$\left.\begin{array}{c}\text { INTERNATIONAL JOURNAL OF } \\ \text { ORGANIZATIONAL LEADERSHIP }\end{array}\right) \begin{gathered}\text { INDUSTRIAL } \\ \text { MANAGEMENT } \\ \text { INSTITUTE }\end{gathered}$

\title{
The role of spiritual intelligence in employees' withdrawal behaviors in physical education organization
}

\author{
Davoud Noroozi ${ }^{1}$, Salehe Abdi Masumabad ${ }^{2} *$ \\ ${ }^{1}$ Young Researchers and Elite, Islamic Azad University, Tabriz Branch, Iran \\ ${ }^{2}$ Young Researchers and Elite, Islamic Azad University, Ardabil Branch, Iran
}

\begin{abstract}
Keywords:

Spiritual Intelligence, Withdrawal Behavior, Physical Withdrawal Behavior, Psychological Withdrawal Behavior

Correspondence:

Leila.abdi22@gmail.com

Spiritual intelligence is the mind's capacity to handle substantial and spiritual aspects of life. According to previous studies, spiritual intelligence can be effective in reducing the withdrawal behavior of employees. This study investigated the effect of spiritual intelligence on employees' withdrawal behavior in Ardabil Physical Education organization. The statistical population of this study included all the employees of Physical Education organization of Ardabil ( $\mathrm{N}=60)$. Descriptive Statistics, Pearson Correlation, and Linear Regression Analyses were used to assess the association between spiritual intelligence and withdrawal behaviors. The results of the study revealed that spiritual intelligence had positive and significant effect on reducing employees' withdrawal behavior. The findings supported that spiritual intelligence training as a new psychological and religious construction may reduce psychological and physical withdrawal behaviors and improve the employees' perception of themselves.
\end{abstract}

(C)AIMI Journals

\section{Introduction}

A growing chorus of scholarly voices is arguing that spirituality is necessary in organizations for ethical behavior, for job satisfaction and employee commitment, and for productivity and competitive advantage (Benefiel, 2005). Organizations continually seek to foster productive and satisfied employees (Barsade, 2002; Gripentrog et al., 2012). Nevertheless, the employees quit their jobs for many different reasons. Having talented team that works hard is 
not enough; organizations should keep their employees on the job for a long period of time and benefit from their efforts (Murphy, 1986). Simply put, organizational commitment is defined as employee's desire to remain with organization (Mowday, Steers, \& Porter, 1979). The counterpoint to the organizational commitment is withdrawal behavior (Kwantes, 2003). Employee's commitment to the organization has effects on the employees themselves, on the organization and on the society. As employees become more committed to the organization, they show reduced withdrawal behaviors and increased citizenship behaviors in their organizations. There are some reasons why employees become disengaged from their work. The most common form of work disengagement is exhibited through job withdrawal behaviors. Job withdrawal refers to behaviors individuals show to avoid aspects of their specific work-role or minimize the time spent on their specific work tasks while maintaining their current organizational and work role (Hanisch \& Hulin, 1990a, 1990b, 1991; Wang \& Yi, 2012). Such behaviors manifest within the workplace and may take either a physical or a psychological form. The reasons behind withdrawal behaviors may be related to job dissatisfaction, job involvement, and organizational commitment (Brooke, Russell, \& Price, 1988). Employee withdrawal consists of behaviors such as absence, lateness, and ultimately job turnover (Bayram, Gursakal, \& Bilgel, 2009; Berry, Lelchook, \& Clark, 2010). In fact, withdrawal behaviors are costly to organizations and organizations need to understand these behaviors (Rosse \& Noel, 1996).

Psychological specialists, management researchers, and practitioners believe that the employees' perception and application of spiritual intelligence as a crucial factor have effect on employees' mental and physical health (Saad, Hatta, \& Mohamad, 2010), productivity, workforce spirit, organizational commitment, job satisfaction, and speed of training new work skills (Charkhabi, Mortazavi, Alimohammadi, \& Hayati, 2014; Newell, 1995). Furthermore, the misuse of spiritual intelligence may also lead to anxiety, absence, lateness, turnover, strike, early retirement, and generally cause job withdrawal behaviors from the organization among employees (Berry, Lelchook, \& Clark, 2010; Herzberg, Mausness, Peterson, \& Capwell, 1957; Hulin, 1991; Johns, 2001; Koslowsky, 2000, 2009; Mobley, 1987).

Nowadays, the two concepts of morality and spirituality are widely discussed by organizations (Fry, 2003; Martin \& Hafer, 2009; Silingiene \& Skeriene, 2014; Weinberg \& Locander, 2014), to name but a few. In the current era, complex environmental phenomenon causes different attitudes, approaches, and responses; regarding to the intensity of the need 
for trust in organizations around the world, the need for the spirituality and spiritual intelligence has increased among employees (Asgari Vaziri \& Zareei, 2011). Considering the different dimensions of spiritual intelligence such as virtuousness, consciousness or self awareness, and the ability to enter higher stages of moral and ethical levels, it can be considered as an important factor affecting employees' withdrawal behavior in Physical Education (PE) organizations. In sum, based on the importance of spiritual intelligence in reducing disengagement and withdrawal behavior in the workplace and the perceived gap in the literature, this study aims to investigate the effect of spiritual intelligence on employees' job withdrawal behavior in Ardabil PE organization.

\section{Spiritual Intelligence}

Spiritual intelligence emerges as a consciousness that evolves into an ever-deepening awareness of matter, life, body, mind, soul, and spirit within different scientific presentations and conferences (Sisk, 2002). Using the word of spiritual intelligence in management and scientific psychology literature was attributed to Zohar and Marshall's (2001) and Emmons' (2000a) activities in the two last two decades (Cowan, 2002; Kalantarkousheh, Sharghi, Soleimani, \& Ramazani, 2014). Drawing on Gardner’s definition of intelligence, Emmons (2000b) argued that spirituality can be viewed as a form of intelligence because it predicts functioning and adaptation and offers capabilities that enable people to solve problems and attain goals (King, 2008). Amram (2009) asserted that spiritual intelligence consists of sense of meaning and having a mission in life, sense of sacredness in life, balanced understanding of material value, and hoping to build a better world. An individual who possess a high degree of spiritual intelligence, tries to look for a response to fundamental questions of life, criticizes the traditions, has flexibility, consciousness, inspiration and intuition, and a holistic view of the world. In a nutshell, spiritual intelligence can simply change people (Samadi, 2006; Shahbakhsh, \& Moallemi, 2013).

Emmons (2000a) argued that spiritual intelligence combines spirituality as an internal structure and intelligence as an external structure into a new structure and develops remarkable capacities in an individual to use spirituality practically. He originally proposed 5 components of spiritual intelligence, including the capacity to transcend the physical and material, the ability to experience heightened states of consciousness, the ability to sanctify everyday experience, the ability to utilize spiritual resources to solve problems, and the capacity to be virtuous to show forgiveness, gratitude, mercy, and humility. 


\section{Withdrawal Behavior}

The scientific study of immoral behavior of organization employees does not have a far longer history than the study of positive behaviors (Colquitt, Baer, Long, \& HalvorsenGanepola, 2014). Although some of these negative and immoral behaviors have individually studied in business settings, the scientific and systematic study of such behaviors has grown in recent years. Withdrawal behaviors refer to those behaviors that can deliberately harm or damage organizations and people in organizations including senior managers, supervisors, employees, clients, and customers. It consists of behaviors such as absence, lateness, and finally job quitting or turnover (Coplan \& Rubin, 2010; Özdemir, Cheah, \& Coplan, 2015; Sackett, Berry, Wiemann, \& Laczo, 2006). Withdrawal comes in two forms: Psychological (or neglect) and physical (or exit).

Physical withdrawal behavior consists of actions that provide a physical escape from the work environment such as tardiness or lateness (Adler \& Golan, 1981; Blau, 1994, 1998), long breaks or physical escape whether short term or long term from working environment, absence, and quitting (Lebreton, Binning, Adorno, \& Melcher, 2004; Pelled \& Xin, 1999; Rosse, 1988). Lateness is defined as arriving late for work or early departure from work (Groeneveld \& Shain, 1985). It shows a lack of motivation to arrive at work on time. One of the most fundamental concepts in administrative and organizational framework is long break. Lack of access to modern technologies, is another cause of wasting time in the organizations. Absenteeism occurs when employees miss a full working day. There are several causes for being absent from work. Researchers divided it into two groups, namely justified absence and unjustified absence (Gupta \& Jenkins, 1991; Hackett, 1989). Employers try to retain their top talent, empower employees to highly manage careers, and reach high levels of productivity by increasing competition and development of human resources. Organizations usually apprehend that they may lose their human resources. Voluntarily leaving the organization is called quitting. It is the most serious form of physical withdrawal behavior (Harman et al., 2007).

Psychological withdrawal behavior comes in number of shapes and sizes, including daydreaming, cyber loafing, and moonlighting (Colquit, LePine, \& Wesson, 2009; Lim, 2002). Daydreaming happens when an employee appears to be working but has a distracted mind and poor attention control over thoughts or concerns. Cyber loafing is the most widespread form of psychological withdrawal among employees (Lim \& Teo, 2005). It is used to describe the actions of employees who surf the Internet during working hours for 
personal use while pretending to do work. It is considered as a new counter-productive work behavior. Engaging in moonlightening is defined as allocating their work time and resources to do or complete a work other than their job duties (Biglaiser \& Ma, 2007). An overview of this study is presented in the conceptual framework given in Figure 1.

\begin{tabular}{|l|l|}
\hline \multicolumn{2}{|c|}{ Spiritual Intelligence } \\
\hline $\begin{array}{l}\text {-The capacity for transcendence } \\
\text {-The ability to enter into } \\
\text { heightened spiritual states of } \\
\text { consciousness } \\
\text {-The capacity to engage in } \\
\text { virtuous behavior } \\
\text {-The ability to invest everyday } \\
\text { activities, events, and relationships } \\
\text { with a sense of the sacred } \\
\text {-The ability to utilize spirituality } \\
\text { resources to solve problems in } \\
\text { living }\end{array}$
\end{tabular}

Figure1. Conceptual framework of research

\section{Research Question}

In line with the discussion above, the following research question was formulated:

Does spiritual intelligence affect the employees' physical and psychological withdrawal behavior in PE organization in Ardabil?

\section{Method}

\section{Participants}

The participants of the study consisted of 60 employees (17 females and 43 males) working at PE organization in Ardabil, Iran. The average age of the participants was 43, with an age range of 29 to 58 years.

\section{Instrument}

In order to collect the data and to test the hypotheses of the study, a questionnaire was developed and distributed among participants. To confirm the validity of the questionnaire, the researchers asked two experts in the field to rate the instrument's efficacy in terms of how effectively it measures participants' use of withdrawal behaviors. The questionnaire consisted 
of two sections; each section included 13 items about spiritual intelligence and withdrawal behavior. Informants were instructed to rate themselves using a five point Likert-Scale where 1 represented very good and 5 very poor. Based on the data gathered, the reliability coefficient alphas were calculated through Cronbach alpha to be 0.78 and 0.81 for two sections respectively.

\section{Results}

The research hypotheses were tested using both the descriptive statistical as well as the inferential statistical method. In addition, Pearson Correlation Coefficient and Multiple Regression have been utilized for data analysis. A one-way ANOVA was run to test the effects of five components of spiritual intelligence on employees' withdrawal behavior. Table 1 presents the means and standard deviations for the spiritual intelligence score of the participants. As shown in Table 1, the mean score of the employees' ability to invest everyday activities, events, and relationships with a sense of the sacred has the highest value among other subscales of spiritual intelligence (Mean $=2.30, \mathrm{SD}=2.57$ ). Furthermore, total mean of spiritual intelligence equaled to 3.50. Results from Table 1 indicate that the mean for subscales of physical and psychological behavior equaled to 1.73 and 2.54, respectively.

\begin{tabular}{lcc} 
Table1 \\
Descriptive Statistics for the Spiritual Intelligence \\
\hline Components & Mean & SD \\
\hline The capacity for transcendence & 1.8 & 3.58 \\
The ability to enter into heightened spiritual states of consciousness & 1.9 & 3.57 \\
The capacity to engage in virtuous behavior & 1.39 & 3.07 \\
The ability to invest everyday activities, events, and relationships with & 2.30 & 2.57 \\
a sense of the sacred & & 3.31 \\
The ability to utilize spirituality resources to solve problems in living & 1.61 & 3.01 \\
Physical Withdrawal Behavior & 1.73 & 3.24 \\
Psychological Withdrawal Behavior & 2.54 & 3.86 \\
Withdrawal Behaviors (total) & 2.83 & 4.12 \\
Spiritual Intelligence (total) & 3.50 & \\
\hline
\end{tabular}

In addition, one-sample Kolmogorov-Smirnov test was conducted to assess whether data had normal distribution. The results of the K-S test (Table 2) indicated that the scores of each component were normally. As a result, parametric tests were used for hypothesis testing.

Multiple regression analysis was used to determine the extent to which predicator variables jointly as well as individually contributed to the prediction of the criterion variables. In this analysis, withdrawal behaviors (physical and psychological) have been considered as 
criterion variables and spiritual intelligence has been taken into account as predicator variable in the regression analysis.

\begin{tabular}{lc}
$\begin{array}{l}\text { Table2 } \\
\text { One-Sample Kolmonogorov-Smirnove Test }\end{array}$ & $\begin{array}{c}\text { Asymp.Sig. } \\
\text { (2-tailed) }\end{array}$ \\
\hline Components & 0.08 \\
& 0.45 \\
\hline The capacity for transcendence & 0.91 \\
The ability to enter into heightened spiritual states of consciousness & 0.13 \\
The capacity to engage in virtuous behavior & 0.65 \\
The ability to invest everyday activities, events, and relationships with a sense of the sacred & 0.16 \\
The ability to utilize spirituality resources to solve problems in living & 0.13 \\
Physical Withdrawal Behavior & 0.25 \\
Psychological Withdrawal Behavior & 0.33 \\
Withdrawal Behaviors (total) & \\
Spiritual Intelligence (total) & \\
\hline
\end{tabular}

The main question addressed in this study was whether the spiritual intelligence would affect the employees' withdrawal behavior. The results indicated that spiritual intelligence of employees showed 48.9\% correlation coefficient with withdrawal behavior and defined $28.1 \%$ of variance of withdrawal behavior. The correlation coefficient between the scores of spiritual intelligence and the withdrawal behavior was 0.48 and it was significant at level $p<$ 0.00. In other words, the effect of spiritual intelligence on withdrawal behavior was significant regarding observed variance ( $F=23.1, p<0.05$ ). According to the negative slope of standard regression coefficient (Beta) and t-ratio, it could be deduced that there was an inverse relation between predicator and criterion, that is, higher scores for SI predicted lower scores on withdrawal behavior. Therefore, spiritual intelligence had positive effect on decreasing the amount of withdrawal behavior.

Table3

Multiple Regression Analysis of Spiritual Intelligence and Withdrawal Behavior

\begin{tabular}{cccccccc}
\multicolumn{2}{c}{ Multiple Regression Analysis of Spiritual Intelligence and Withdrawal Behavior } \\
\hline Variable & $\begin{array}{c}\text { Correlation } \\
\text { Coefficient(R) }\end{array}$ & $\begin{array}{c}\text { Square of } \\
\text { Correlation } \\
\text { Coefficient } \\
\left(\mathrm{R}^{2}\right)\end{array}$ & $\mathrm{B}$ & $\begin{array}{c}\text { Standard } \\
\text { Regression } \\
\text { Coefficient } \\
(\text { Beta) }\end{array}$ & t-ratio & $\begin{array}{c}\text { Value } \\
\text { F }\end{array}$ & $p$ \\
\hline $\begin{array}{c}\text { Spiritual } \\
\text { Intelligence }\end{array}$ & 0.48 & 0.28 & 0.27 & -0.22 & -4.8 & 23.1 & 0.00 \\
\hline
\end{tabular}

In order to assess the impact of spiritual intelligence on employees’ physical withdrawal behavior further analyses were done. Table 4 displays the summary of the information about the obtained ratios from the regression analysis of spiritual intelligence on employees. The second regression analysis also was run to evaluate the predictive value of spiritual intelligence variable on the criterion variable of physical withdrawal behavior. The 
correlation coefficient between the scores of spiritual intelligence and physical withdrawal behavior was 0.41 and it was significant at level $p<0.00$. It can be explained $23.1 \%$ of variance of physical withdrawal behavior as criterion variable. According to the negative slope of standard regression coefficient (Beta) and t-ratio, there was an inverse relation between predicator and criterion, that is, higher scores for spiritual intelligence predicted lower scores on physical withdrawal behavior. Therefore, spiritual intelligence had positive effect on decreasing the amount of physical withdrawal behavior.

Table4

Multiple Regression Analysis of Spiritual Intelligence and Physical Withdrawal Behavior

\begin{tabular}{cccccccc}
\hline Variable & $\mathrm{R}$ & $\begin{array}{c}\mathrm{R} \text { square } \\
\left(\mathrm{R}^{2}\right)\end{array}$ & $\mathrm{B}$ & $\mathrm{Beta}$ & $\mathrm{t}$ & $\mathrm{F}$ & $p$ \\
\hline $\begin{array}{c}\text { Spiritual } \\
\text { Intelligence }\end{array}$ & 0.41 & 0.23 & 0.20 & -0.19 & -3.9 & 22.13 & 0.00 \\
\hline
\end{tabular}

As Table 5 indicates, the obtained $\mathrm{F}$ value was statistically significant which indicated statistically significance of the relationship between spiritual intelligence and psychological withdrawal behavior. The predictive variable spiritual intelligence could predict the criterion variable (psychological withdrawal behavior). Therefore, regression analysis was allowed and feasible.

Table 5

Multiple Regression Analysis of Spiritual Intelligence and psychological Withdrawal Behavior

\begin{tabular}{cccccccc}
\hline Variable & $\mathrm{R}$ & $\begin{array}{c}\mathrm{R} \text { square } \\
\left(\mathrm{R}^{2}\right)\end{array}$ & $\mathrm{B}$ & Beta & $\mathrm{t}$ & $\mathrm{F}$ & $p$ \\
\hline $\begin{array}{c}\text { Spiritual } \\
\text { Intelligence }\end{array}$ & 0.51 & 0.31 & 0.30 & -0.26 & -6.2 & 24.61 & 0.00 \\
\hline
\end{tabular}

According to Table 5, spiritual intelligence played a key role in predicting psychological withdrawal behavior, that is, higher scores for spiritual intelligence predicted lower scores on physical withdrawal behavior. The negative slope of Beta implied an inverse relation between dependent and independent variables of the study. Therefore, spiritual intelligence had positive impact on decreasing the amount of psychological withdrawal behavior.

\section{Discussion}

The present study set out to investigate the influence of spiritual intelligence on employees' withdrawal behavior in PE organization. The positive effects of spiritual intelligence in promotion of an organization's effectiveness and individual growth of employees were considered in this study. Results indicated a statistically significant relationship between spiritual intelligence and withdrawal behavior. Through application of spiritual intelligence 
components, employees would experience less exhaustion and it would enhance the organizational efficiency and effectiveness. It gives the managers and employees a broader perspective and ability to create, convert, and transform organizational values. Spirituality in workplace leads to improved organizational performance and is addressed by lasting organizational excellence (Case \& Gosling, 2010; Corbett, 2009). Having ability to enhance spiritual intelligence components such as the ability to engage in virtuous behavior and invest everyday activities, events, and relationships with a sense of the sacred can help employees overcome withdrawal behaviors. Spiritual intelligence provides an opportunity to change the situation for better managing. It is the intelligence that gives deeper sense of fulfillment and satisfaction to high levels of our life. The growth of spiritual intelligence helps us achieve a new level of understanding of ourselves and increase our self-confidence in order to have a stable self and decrease our daily tensions. Furthermore, it can add a sense of depth and richness to communications. Malik and Naeem (2011) concluded that dimensions of spiritual intelligence had a positive relationship with promotion of organizational commitment and reduction of withdrawal behaviors.

This study can be replicated in a wide range in order to help the managers and supervisors to make a firm judgment about the importance of withdrawal behavior. Determining the relative contribution of withdrawal behaviors may have an effect on efficiency and optimized performance of organizations. Therefore, successful organizations should be compared with unsuccessful ones based on their performance, human beings communications, quality of products, and servicing.

There are a limited number of studies in this field, thus the need exists for further research. Further studies should research the effect of spiritual intelligence on organizational functioning, the relationship between spiritual intelligence and withdrawal behaviors, and the role of spiritual intelligence in the improvement of affective commitment in an assumed organization in different populations and in different contexts.

\section{References}

Adler, S., \& Golan, J. (1981). Lateness as a withdrawal behavior. Journal of Applied Psychology, 66, 544-554.

Amram, Y. (2009). The contribution of emotional and spiritual intelligence to effective business leadership (Unpublished doctorial dissertation). Institute of Transpersonal Psychology, California, Palo Alto.

Asgari Vaziri, A., \& Zareei, M. H. (2011). Spiritual intelligence and its role in the workplace based on religious teaching notes. Journal of Islamic \& Administrative Studies, 1(3), 63-90.

Barsade, S. G. (2002). The ripple effects: Emotional contagion and its influence on group behavior. Administrative Science Quarterly, 47, 644-675. 
Bayram, N., Gursakal, N., \& Bilgel, N. (2009). Counterproductive work behavior among white-collar employees: A study from Turkey. International Journal of Selection \& Assessment, 17(2), 180-188.

Benefiel, M. (2005). The second half of the journey: Spiritual leadership for organizational transformation. The Leadership Quarterly, 16,723-747.

Berry, C. M., Lelchook, A. M., \& Clark, M. A. (2010). A meta-analysis of the interrelationships between employee lateness, absenteeism, and turnover: Implications for models of withdrawal behavior. Journal of Organizational Behavior, 33, 678699.

Biglaiser, G., \& Ma, A. C. (2007). Moonlighting: Public service and private practice. The RAND Journal of Economics, 38, 1113-1133.

Blau, G. (1994). Developing and testing a taxonomy of lateness behavior. Journal of Applied Psychology, 79, 959-970.

Blau, G. (1998). On the aggregation of individual withdrawal behaviors into larger multi-item constructs. Journal of Organizational Behavior, 19, 437-451.

Brooke, P. P., Russell, D. W., \& Price, J. L. (1988). Discriminant validation of measures of job satisfaction, job involvement, and organizational commitment. Journal of Applied Psychology, 73, 139-45.

Case, P., \& Gosling, J. (2010). The spiritual organization: Critical reflections on the instrumentality of workplace spirituality. Journal of Management, Spirituality, \& Religion, 7(4), 257-282.

Charkhabi, M., Mortazavi, A., Alimohammadi, S., \& Hayati, D. (2014). The effect of the spiritual intelligence training on the indicators of mental health in Iranian students: An experimental study. Procedia- Social \& Behavioral Sciences, 159, 355-358.

Colquitt, J., LePine, J. A., \&Wesson, M. J. (2009). Organizational behavior: Essentials for improving performance \& commitment. Boston: McGraw Hill/Irwin.

Colquitt, J. A., Baer, M. D., Long, D. M., \& Halvorsen-Ganepola, M. D. K. (2014). Scale indicators of social exchange relationships: A comparison of relative content validity. Journal of Applied Psychology, 99(4), 599-618.

Coplan, R. J., \& Rubin, K. H. (2010). Social withdrawal and shyness in childhood: History, theories, definitions, and assessments. In K. H. Rubin, \& R. J. Coplan (Eds.), The development of shyness and social withdrawal (pp. 3-20). New York: The Guilford Press.

Corbett, J. M. (2009). Invoking spirits in the material world: Spiritualism, surrealism, and spirituality at work. Management \& Organizational History, 4(4), 339-357.

Cowan, D. A. (2002). Translating spiritual intelligence into leadership competencies. Journal of Management, Spirituality, \& Religion, 2(1), 3-38.

Emmons, R. A. (2000a). Is spirituality an intelligence? Motivation, cognition, and the psychology of ultimate concern. International Journal for the Psychology of Religion, 10(1), 3-26.

Emmons, R. A. (2000b). Spirituality and intelligence: Problems and prospects. International Journal for the Psychology of Religion, 10(1), 57-64.

Fry, L. W. (2003). Toward a theory of spiritual leadership. The Leadership Quarterly, 14, 693-727.

Gripentrog, B. K., Harold, C. M., Holtz, B. C., Klimoski, R. J., \& Marsh, S. M. (2012). Integrating social identity and the theory of planned behavior: Predicting withdrawal from an organizational recruitment process. Personal Psychology, 65, 723- 753.

Groeneveld, J., \& Shain, M. (1985). The effect of corrective interviews with alcohol dependent employees: A study of 37 supervisor subordinate dyads. Employee Assistance Quarterly, 1(1), 63-73.

Gupta, N., \& Jenkins, G. D. (1991). Absenteeism and turnover: Is there a progression? Journal of Management Studies, 9(4), 395-412.

Hackett, R. D. (1989). Work attitudes and employee absenteeism: A synthesis of the literature. Journal of Occupational Psychology, 62, 235-248.

Hanisch, K. A., \& Hulin, C. L. (1990a). Job attitudes and organizational withdrawal: An examination of retirement and other voluntary withdrawal behaviors. Journal of Vocational Behavior, 37, 60-78.

Hanisch, K. A., \& Hulin, C. L. (1990b). Retirement as a voluntary organizational withdrawal behavior. Journal of Vocational Behavior, 37, 60-78.

Hanisch, K. A., \& Hulin, C. L. (1991). General attitudes and organizational withdrawal: An evaluation of a causal model. Journal of Vocational Behavior, 39, 110-28.

Harman, W. S., Lee, T. W., Mitchell, T. R., Felps, W., \& Owens, B. P. (2007). The psychology of voluntary employee turnover. Current Directions in Psychological Science, 16, 51-54. 
Herzberg, F., Mausness, B., Peterson, R., \& Capwell, D. (1957). Job attitudes: Review of research \& opinion. Pittsburg: Psychological Services.

Hulin, C. L. (1991). Adaptation, persistence, and commitment in organizations. In M. D. Dunnette, \& L. M. Hough (Eds.), Handbook of industrial and organizational psychology (pp. 445-505). Palo Alto, CA: Consulting Psychologists Press.

Johns, G. (2001). The psychology of lateness, absenteeism, and turnover. In N. Anderson, D. Ones, H. Sinangil, \& C.

Viswesvaran (Eds.), Handbook of industrial, work, and organizational psychology (pp. 233-252). London: Sage.

Kalantarkousheh, M., Sharghi, N., Soleimani, M., Ramezani, S. (2014). The role of spiritual intelligence on organizational commitment in employees of Universities in Tehran Province, Iran. Procedia: Social \& Behavioral Sciences, 140, 499505.

King, D. B. (2008). Rethinking claims of spiritual intelligence: A definition, model, and measure (unpublished master's thesis). Trent University, Peterborough, Ontario, Canada.

Koslowsky, M. (2000). A new perspective on employee lateness. Applied Psychology: An International Review, 49, 390407.

Koslowsky, M. (2009). A multi-level model of withdrawal: Integrating and synthesizing theory and findings. Human Resources Management Review, 19, 283-303.

Kwantes, C. T. (2003). Organizational citizenship and withdrawal behaviors in the USA and India: Does commitment make a difference? International Journal of Cross Cultural Management, 3(1), 5-26.

Lebreton, J. M., Binning, J. F., Adorno, A. J., \& Melcher, K. M. (2004). Importance of personality and job specific affect for predicting job attitudes and withdrawal behavior. Organizational Research Methods, 7(3), 300-325.

Lim, V. K. G. (2002). The IT way of loafing on the job: Cyber loafing, neutralizing and organizational justice. Journal of Organizational Behavior, 23(5), 675-694.

Lim, V. K. G., \& Teo, T. S. H. (2005). Prevalence, perceived seriousness, justification, and regulation of cyber loafing in Singapore: An exploratory study. Information \& Management, 42, 1081-1093.

Malik, M. E., \& Naeem, B. (2011). Role of spirituality in job satisfaction and organizational commitment among faculty of institutes of higher learning in Pakistan. African Journal of Business Management, 5(4), 1236-1244.

Martin, T. N., \& Hafer, J. C. (2009). Models of emotional intelligence, and performance: A test of Tischler, Biberman, and McKeage. Journal of Management, Spirituality, \& Religion, 6(3), 247-257.

Mobley, W. H. (1987). Intermediate linkage in the relationship between job satisfaction and turnover. Journal of Applied Psychology, 62, 237-240.

Mowday, R., Steers, R. M., \& Porter, L. (1979). The measurement of organizational commitment. Journal of Vocational Behavior, 14, 224-247.

Murphy, K. A. (1986). When your top choice turns you down: Effect of rejected job offers on the utility of selection tests. Psychological Bulletin, 99, 128-133.

Newell, S. (1995). The healthy organization. London: Routledge.

Özdemir, S. B., Cheah, C. S. L., \& Coplan, R. J. (2015). Conceptualization and assessment of multiple forms of social withdrawal in Turkey. Social Development, 24(1), 143-165.

Pelled, L. H., Xin, K. R. (1999). Down and out: An investigation of the relationship between mood and employee

withdrawal behavior. Journal of Management, 25(6), 875-895.

Rosse, J. G. (1988). Relations among lateness, absence, and turnover: Is there a progression of withdrawal? Human Relations, 41(7), 517-531.

Rosse, J. G., \& Noel, T. W. (1996). Leaving the organization. In K. R. Murphy (Eds.), Individual difference and behavior in organizations (pp. 451-494). San Francisco, CA: Jossey-Bass.

Sackett, P. R., Berry, C. M., Wiemann, S., \& Laczo, R. M. (2006). Citizenship and counter-productive work behavior: Clarifying relationship between the two domains. Human Performance, 19(4), 441-464.

Saad, M. Z., Hatta, Z. A., Mohamad, N. (2010). The impact of spiritual intelligence on the health of the elderly in Malaysia Asian Social Work \& Policy Review, 4, 84-97.

Samadi, P. (2006). Spiritual intelligence. Journal of Modern Educational Thought, 2(3), 99-144.

Shahbakhsh, B., \& Moallemi, S. (2013). Spiritual intelligence, resiliency, and withdrawal time in clients of methadone maintenance treatment. International Journal of High Risk Behaviors \& Addiction, 2(3), 132-135. 
Sisk, D. (2002). Spiritual intelligence: The tenth intelligence that integrates all other intelligences. Gifted Education International, 16, 208-212.

Silingiene, V., \& Skeriene, S. (2014). Expression of leaders' spiritual intelligence in a context of organizations' services quality: A theoretical approach. Procedia- Social \& Behavioral Sciences, 156, 93-97.

Wang, S., \& Yi, X. (2012). Organizational justice and work withdrawal in Chinese companies: The moderating effects of allocentrism and idiocentrism. International Journal of Cross Cultural Management, 12(2), 211-228.

Weinberg, F. J., \& Locander, W. B. (2014). Advancing workplace spiritual development: A dyadic mentoring approach. The Leadership Quarterly, 25, 391-408.

Zohar, D., \& Marshall, I. (2001). SQ: Spiritual intelligence the ultimate intelligence. London: Bloomsbury Publishing. 